\title{
Livelihoods of Ornamental Coral Fishermen in South Sulawesi/Indonesia: Implications for Management
}

\author{
Sebastian C.A. Ferse, Leyla Knittweis , Gesche Krause , Andi Maddusila \& \\ Marion Glaser
}

To cite this article: Sebastian C.A. Ferse, Leyla Knittweis, Gesche Krause , Andi Maddusila \& Marion Glaser (2012) Livelihoods of Ornamental Coral Fishermen in South Sulawesi/ Indonesia: Implications for Management, Coastal Management, 40:5, 525-555, DOI: 10.1080/08920753.2012.694801

To link to this article: https://doi.org/10.1080/08920753.2012.694801

\section{(2) Copyright Taylor and Francis Group, LLC}

\section{Published online: 10 Sep 2012.}

\section{Submit your article to this journal \ulcorner}

Џ Article views: 1104

a

View related articles $[\pi$

Citing articles: 24 View citing articles $\asymp$ 


\title{
Livelihoods of Ornamental Coral Fishermen in South Sulawesi/Indonesia: Implications for Management
}

\author{
SEBASTIAN C.A. FERSE, ${ }^{1}$ LEYLA KNITTWEIS, ${ }^{1}$ GESCHE \\ KRAUSE, ${ }^{1}$ ANDI MADDUSILA, ${ }^{2}$ AND MARION GLASER ${ }^{1}$ \\ ${ }^{1}$ Leibniz Center for Tropical Marine Ecology (ZMT), Bremen, Germany \\ ${ }^{2}$ Center for Coral Reef Research (CCRR), Hasanuddin University (UNHAS), \\ Makassar, Indonesia
}

\begin{abstract}
Collection of live coral for the marine aquarium trade has increased significantly in recent years, causing concerns over the ecological implications of this activity for the source regions. The Spermonde Archipelago off Southwest Sulawesi is one of the four major ornamental coral collection sites in Indonesia, the country supplying most corals in the trade. Management of the fishery remains ineffective, and overharvesting is widespread. Conservation strategies for marine resources increasingly emphasize the socioeconomic dimensions of resource use, yet little information is available on the livelihoods of fishermen involved in the ornamental fishery. Here, a first analysis of the livelihoods of coral fishermen in the Spermonde Archipelago is presented, along with a discussion of possibilities for future management interventions. The reef fishery of the study area is characterized by a high diversity of target organisms, with none of the fishermen relying exclusively on ornamental corals for income. Moreover, fishermen are organized in a tightly knit web of patron-client relationships, leaving little scope for them to initiate changes in livelihood strategies. The patron-client system emerged as a key institution of the fishery. In order to support sustainable marine resource use, management policies should simultaneously target the fishermen and their patrons as well as the regional coral trade network, broadening the livelihood portfolio of island communities and improving the regulation of the associated trade network.
\end{abstract}

This study was carried out within the frame of the bilateral Indonesian-German research program SPICE I and II (Science for the Protection of Indonesian Coastal Marine Ecosystems) sponsored by the German Federal Ministry of Education and Research (Grants No. 03F0390A and 03F0474A), the Indonesian Ministry of Marine Affairs and Fisheries (KKP), and the Ministry for Research and Technology (RISTEK). The funders had no involvement in study design, data analysis, or publication. We thank the former Center for Coral Reef Research (CCRR, since 2011 reorganized as Marine, Coastal and Small Islands R\&D Center) at Hasanuddin University in Makassar for their kind support and collaboration, R. Deswandi, M. Kasmi, I. Radjawali, S. Husain and K. Schwerdtner Máñez for fruitful discussions and comments, and M. Nugues for driving two of the authors (SCAF \& MG) through a horrid snowstorm while working on the article. The comments of two anonymous reviewers helped to improve this article.

Current affiliation for Leyla Knittweis: Fisheries Control Directorate (FCD), Ministry for Resources and Rural Affairs (MRRA), Valletta, Malta.

Current affiliation for Gesche Krause: SeaKult Consulting, Bremerhaven, Germany.

Address correspondence to Sebastian C.A. Ferse, Leibniz Center for Tropical Marine Ecology (ZMT), Fahrenheitstraße 6, D-28359, Bremen, Germany. E-mail: sebastian.ferse@ zmt-bremen.de 
Keywords coral trade, Indonesia, livelihood diversification, middlemen, ornamental fishery

\section{Introduction}

Since the widely publicized coral bleaching event in 1998, the plight of coral reefs has increasingly come into public focus, fueled by scientists' predictions of widespread coral loss due to global climate change within the coming decades (e.g., Hoegh-Guldberg 1999; Hoegh-Guldberg et al. 2007). Localized human activities are also increasingly impacting reefs so that over $60 \%$ of reefs worldwide are now immediately threatened by local activities such as (over)fishing and coastal development. These threats are particularly severe in Southeast Asia, where nearly $95 \%$ of the reefs are threatened, causing widespread concern over their conservation (Burke et al. 2011). At the same time, human use of coral reef resources has been steadily increasing. A case in point is the collection of live animals for the marine ornamental trade, which over the past three decades, in the wake of technological advances that increased the ability of hobbyists to maintain marine animals in captivity, has developed into a multi-million-dollar industry.

The collection of marine ornamental species has become an important economic factor in some source regions, but detailed information on its contribution to the livelihoods of coastal communities is largely missing (Wabnitz et al. 2003; Watson 2000). Today, an estimated 40 to 46 million animals are traded per year, worth an approximate 200 to 330 million USD. Stony corals make up about one quarter of the specimens traded (Wabnitz et al. 2003). Over $90 \%$ of the corals traded originate in Indonesia, the country with the largest area of threatened reefs worldwide (Burke et al. 2011; Jones 2008). The collection of stony corals can have considerable local impacts, altering the reef community structure and causing decreases in live coral cover. This has led to concerns over the sustainability of stony coral collection, and to the listing of all stony corals under Appendix II of the Convention on International Trade in Endangered Species (CITES). The latter requires that their international trade be regulated to ensure that it is not detrimental to the species (Harriott 2003; Ross 1984). Until now, the overwhelming majority of ornamentals are collected from the wild: according to Wabnitz et al. (2003), captive bred and reared marine species make up just 1-2\% of the global trade. Efforts to develop captive cultivation have been limited by biological and socioeconomic feasibility constraints such as difficulties in feed supply and larval rearing, lack of knowledge on life histories of target species, lack of low-tech culture methods and appropriate handling, limited financial and technical assistance, and elite capture in source regions such as Indonesia (Job 2005; Moorhead and Zeng 2010; Pomeroy and Balboa 2004).

It is widely accepted today that successful marine conservation requires the consideration of the socioeconomic dimensions of resource use, including users' priorities (e.g., Lundquist and Granek 2005; Norse and Crowder 2005). Management interventions aiming at a diversification of livelihoods, such as supplemental livelihood programs, are frequently proposed as parts of coral reef conservation strategies (e.g., Gillet et al. 2008). A case in point is the development of marine aquaculture, or mariculture, with its potential to diversify fisherfolk's livelihoods, to reduce pressure on local coral reef resources and to alleviate poverty in local fishing communities. Mariculture of animals popular with aquarists is increasingly called for to relieve pressure on coral reefs, particularly with respect to harvesting live animals for the ornamental trade (Parks, Pomeroy, and Balboa 2003). However, in order to establish to which extent options such as aquaculture are an alternative to fishing, factors such as available assets, income-generating activities, and attitudes toward these have to be considered (Crawford 2002; Miyata and Manatunge 2004; Sievanen et al. 
2005). More often than not, socioeconomic aspects are the decisive factor determining the success of ecologically well-designed marine conservation efforts (Sale et al. 2005).

The sustainable livelihoods framework, which analyses human access to physical, natural, human, financial, and social capital (Scoones 1998; DFID 1999), constitutes a suitable analytical framework to assess the asset base and income portfolio of coastal communities (Allison and Ellis 2001). Livelihood diversification has been advocated as a key strategy to decrease vulnerability in the face of uncertainty, which can, for instance, stem from dependence on resources that are subject to considerable fluctuations (Ellis 2000). Reviews of rural agricultural household livelihood strategies stress the importance of diversifying income generation activities to support the livelihoods of rural families in developing countries (Ellis 1998; 2000; Niehof 2004). Studies from the Western Pacific suggest that diversification into non-fishing activities constitutes an important strategy for coastal communities (Cinner, Marnane, and McClanahan 2005; Turner et al. 2007). In contrast to the vast number of studies carried out on poor rural households in agricultural systems, research that focuses on livelihood strategies of fisherfolk households in tropical regions is still limited. Even fewer studies to date deal with the livelihoods of ornamental fishermen (Watson 2000).

In this article, we provide a comprehensive overview of the current livelihoods of fishers engaged in the ornamental coral fishery of the Spermonde Archipelago, South Sulawesi, Indonesia. This area has emerged as one of the major collection areas for the international coral trade in recent decades. Local attitudes, perceptions, and networks related to the fishery are examined, and implications for management options are discussed. Following an analysis of the development and organization of the fishery and of the livelihood assets available to its various actors, we discuss local rationalities surrounding the option to adopt small-scale mariculture as an alternative livelihood option.

Next, the implications of the current livelihoods of islanders involved in the ornamental coral fishery and the institutional contexts they operate in for future livelihood development are discussed. The final section of the article provides recommendations for marine conservation policies that aim at improving fisherfolk livelihoods and a sustainable management of the fishery.

\section{Materials and Methods}

\section{The Study Area}

Indonesia is a vast archipelago of over 17,000 islands situated between the eastern Indian Ocean and the western Pacific. The region is characterized by a variety of highly productive coastal ecosystems, which support one of the largest marine fisheries in the world (Hopley and Suharsono 2000). Over 80\% of Indonesia's estimated 240 million people live within $50 \mathrm{~km}$ of the coast. Artisanal fisheries play an important role in the country, making up more than $95 \%$ of its total marine fisheries production (Burke, Selig, and Spalding 2002). Human interactions with coral reefs in Indonesia date back to prehistoric times (Polunin 1983). Some current reef fisheries, such as the collection of sea cucumbers, have been ongoing for several centuries, and have since long ago linked Indonesian fishing communities to distant markets (Butcher 2004; Schwerdtner Máñez and Ferse 2010). However, the unsustainable use of resources has risen dramatically over the past decades with increasing demands from growing populations, international trade and changing consumption patterns (Miclat, Ingles, and Dumaup 2006). Cyanide fishing for the live food and aquarium fish trades, blast fishing, coral mining for construction materials and the aquarium trade, land-based pollution and general overfishing have had considerable cumulative impacts on reefs over time (Barber 
and Pratt 1997; Burke, Selig, and Spalding 2002). Today, over 90\% of Indonesia's coral reefs are under threat from such activities (Burke et al. 2011).

The study area, the Spermonde Archipelago off the coast of Makassar in South Sulawesi, extends about $60 \mathrm{~km}$ offshore and consists of more than 100 islands with fringing reefs as well as a large number of barrier and submerged patch reefs (Tomascik et al. 1997). An estimated 6,500 fishing households reside on the various islands and depend on the reefs for their livelihoods. Scarce employment alternatives cause fishing efforts to remain high throughout the year (Pet-Soede et al. 2001). Reef degradation is widespread (Edinger et al. 1998), with few recent improvements in management strategies despite the fact that scientists have, for more than a decade, been warning that the reef ecosystem may be on the verge of collapse (Erdmann 1995). As fish are becoming rarer, corals are selectively harvested over large areas for the aquarium trade in Spermonde (Bruckner 2002). Massive corals have been utilized by islanders as building materials for centuries. This practice has, however, been declining in recent years due to increasing local awareness on the negative impacts this has on coral reefs, and due to the availability of alternative construction materials on the islands, such as cement and limestone rocks from the mainland. The collection of corals for the ornamental trade focuses on smaller colonies and on particularly colorful morphs. During initial visits to the area, two islands were found to be of primary importance in the ornamental coral trade: Karanrang and Barrang Lompo. While Barrang Lompo is close to the port of Makassar and has been an important hub of the Spermonde trade and fishery for centuries, Karanrang is located more to the north, in the center of the archipelago (Figure 1).

Fishing is by far the dominant source of livelihood on the Spermonde islands. A detailed survey in 2008 of every second household on Badi, an island halfway between Karanrang and Barrang Lompo, found that $73 \%$ of the men were fishers, $52 \%$ of the women categorized themselves as "housewives," $18 \%$ of the respondents (male and female) were traders, and $4 \%$ (male and female) were entrepreneurs. A further $12 \%$ had other jobs (Ferse unpublished data). These percentages correspond largely to an official breakdown of occupations for the wider area (BPS 2009). Current official statistics record approximately 4,200 inhabitants for Barrang Lompo (BPS 2010), while the island government estimates the number of fishermen at around 2,000 (cited in Martens 2009). However, as only males are involved in fishing, the latter number may be an overestimate. On Karanrang, where there are about 3,000 inhabitants, the number of fishermen is estimated at around 640 (BPS 2009).

Partly due to the proximity to Makassar airport, the Spermonde Archipelago has become one of four major coral collection sites in Indonesia (Raymakers 2001). The country supplies over $90 \%$ of the estimated 11-12 million pieces of stony coral traded globally per year (Jones 2008; Wabnitz et al. 2003). Over $80 \%$ of the live corals from Indonesia are exported to the United States and the European Union, and another $10 \%$ of Indonesian corals are imported by Japan. Exports to China (mainly to Hong Kong) make up less than $2 \%$ of the trade (Raymakers 2001). The harvest of key species for the international ornamental trade, such as the mushroom coral Heliofungia actiniformis, is resulting in severe overfishing at targeted reefs in Spermonde (Knittweis and Wolff 2010). Similarly, Bruckner and Borneman (2006) estimated that over half of the stocks of several target species were removed within just one year, underlining the need for effective management of the fishery. There are only an estimated 100 fishers involved in the ornamental coral fishery in Spermonde (Bruckner and Borneman 2006), so that the individual contribution of each fisher is relatively large.

\section{Interviews}

Initial information on the ornamental coral fishery in Spermonde was gathered during a two-year field study between 2005 and 2007 (Knittweis 2008). In March 2008, additional 


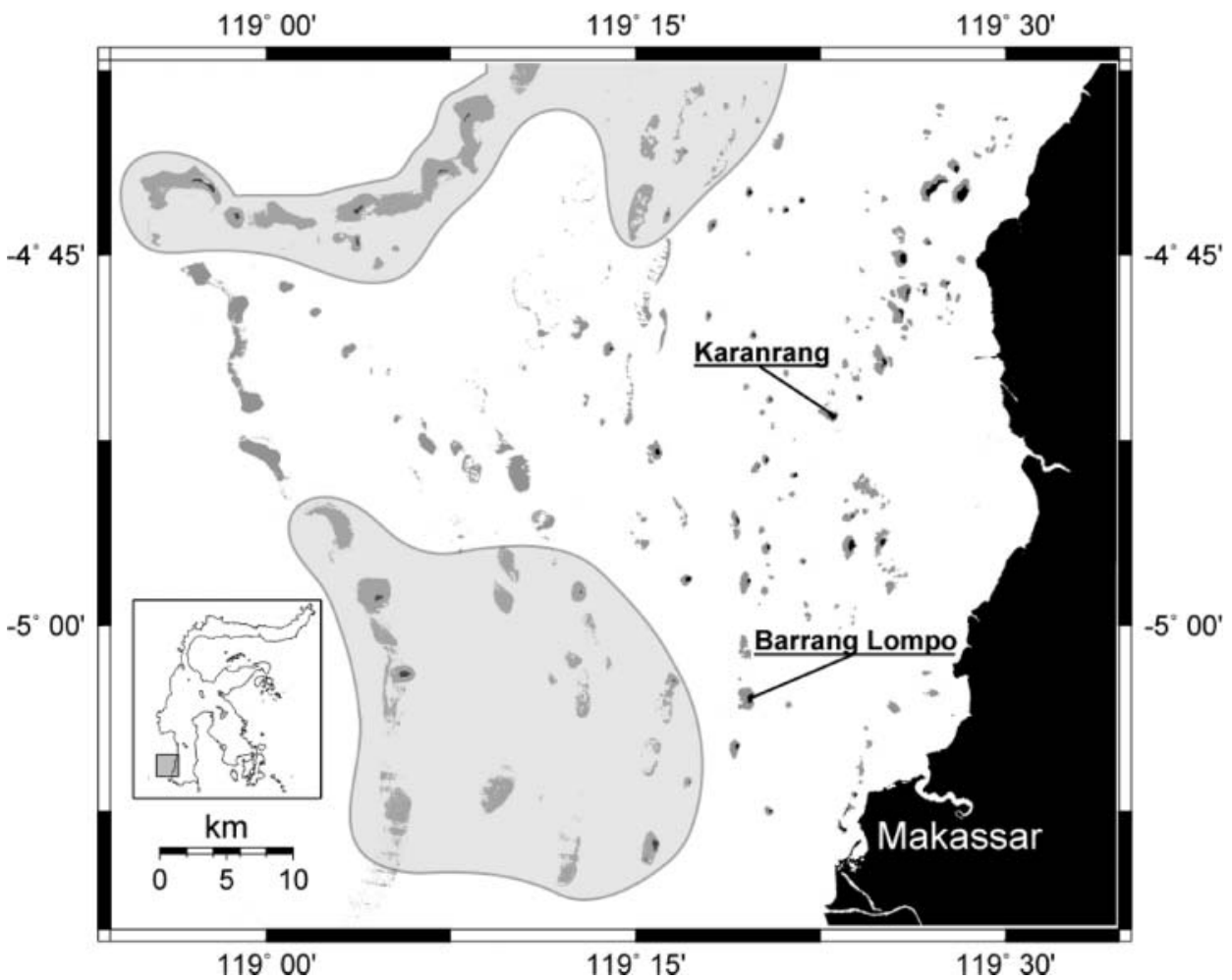

Figure 1. Map of the Spermonde Archipelago in South Sulawesi, showing the research locations and current important coral collecting grounds based on interviews in the present study (shaded areas). Since fishermen engaged in collection of ornamentals are opportunistic, other areas are also infrequently subject to collection pressure. Note that key collection grounds differ over time and according to species (see text).

key informant interviews with 12 persons directly involved in the ornamental coral trade (trade company owners and middlemen) and 14 further local stakeholders (village elders, nongovernmental organization [NGO] personnel and researchers at Hasanuddin University (UNHAS) in Makassar) were conducted to collect background information on the ornamentals trade in Spermonde. Questionnaire-based interviews combining semi-structured and closed survey questions designed to generate detailed information on island-based actors involved in the Spermonde ornamental coral trade (following Bunce et al. 2000) were then conducted during a series of visits to Karanrang and Barrang Lompo in June and July 2008. These interviews investigated:

- the respondents' background and current role in the ornamental coral and other fisheries

- respondents' involvement and status in the local patron-client system

- the livelihood assets of respondents and their households

General housing conditions, household items necessary for the ornamental fishery (e.g., boats and compressors), and household items indicating material wealth (e.g., TV sets, refrigerators, and motorcycles) were assessed. For each person interviewed, additional data was collected on age, the year in which they began collecting ornamental corals, 
estimated average weekly income from the trade in ornamental corals in the previous year, seasonality in the fishery, income sources besides ornamentals, number, age and education of household members, as well as attitudes toward mariculture. As with all types of fishing in Spermonde (except reef gleaning), the ornamental coral fishery is an exclusively male activity. All of the interviewed coral collectors were therefore men. Respondents $(n=34$ and $n=20$ for Karanrang and Barrang Lompo, respectively) were randomly selected and interviewed based on consent and availability, for instance by their presence at sorting sites for ornamental coral species. According to a marine ornamental trader from Makassar with good knowledge of the ornamental coral fishery, the majority of those involved in the fishery on the two islands was interviewed in our study (M. Kasmi, personal communication, December 2009).

Further observations and non-formal interviews were done during subsequent visits to the area between February 2009 and March 2010. During these visits, semi-structured interviews with various islanders, selected by purposive sampling, were conducted on a number of islands in Spermonde to obtain more detailed information on trade and fishing networks, patron-client relationships, and management options (see Glaser et al. 2010a on the research approach used). In order to arrive at locally more meaningful conclusions, some of the findings and implications of the questionnaire interviews were discussed with local stakeholders. All interviews were conducted in Indonesian (Bahasa Indonesia), either by the authors themselves, or by staff of the Centre for Coral Reef Resources (PPTK, Pusat Penelitian Terumbu Karang) at UNHAS.

For nominal data, differences in the frequency of items between different categories of respondents were assessed using a mid- $p$ version of the Freeman-Halton extended Fisher exact test (Ruxton and Neuhäuser 2010). A non-parametric Kruskal-Wallis test was used for continuous data. For the Fisher-Freeman-Halton test, an online tool (available at http://www.vassarstats.net) was used. For the Kruskal-Wallis test, the statistics package SPSS 17 was used.

\section{Results and Discussion}

\section{General Characteristics of the Ornamental Coral Fishery}

While all respondents on Barrang Lompo were fishermen, five respondents on Karanrang were punggawas (patrons). Three of the latter were patrons with a bigger business network and capital at their disposal, while the remaining two were "small" local punggawas. These patron categories are types of middlemen described in more detail in Table 1 and in the section on informal institutions below. In $36 \%$ of the interviewed households on Barrang Lompo $(n=14)$, several members of the same household were involved in the ornamental coral fishery. On both islands, fishermen belonged to one of two groups of similar size (Table 2): either those for whom the ornamental coral fishery was their primary income, or those for whom it was a supplementary activity, with their main income derived from fishing for other species. These groups represent opposite ends of a continuum, with the relative importance of ornamental fishing for the household ranging from low to high. None of the interviewed fishermen depended exclusively on ornamental coral species for their livelihood, and most collected corals opportunistically (i.e., whenever they encountered them during diving). Even among those who considered the ornamental coral fishery as their primary source of income, only a minority (Barrang Lompo: $n=2$, Karanrang: $n=$ 6) focused specifically on collecting corals for the ornamental trade. The majority either targeted sunu (red grouper) or had no particular target species. The primary income of those 


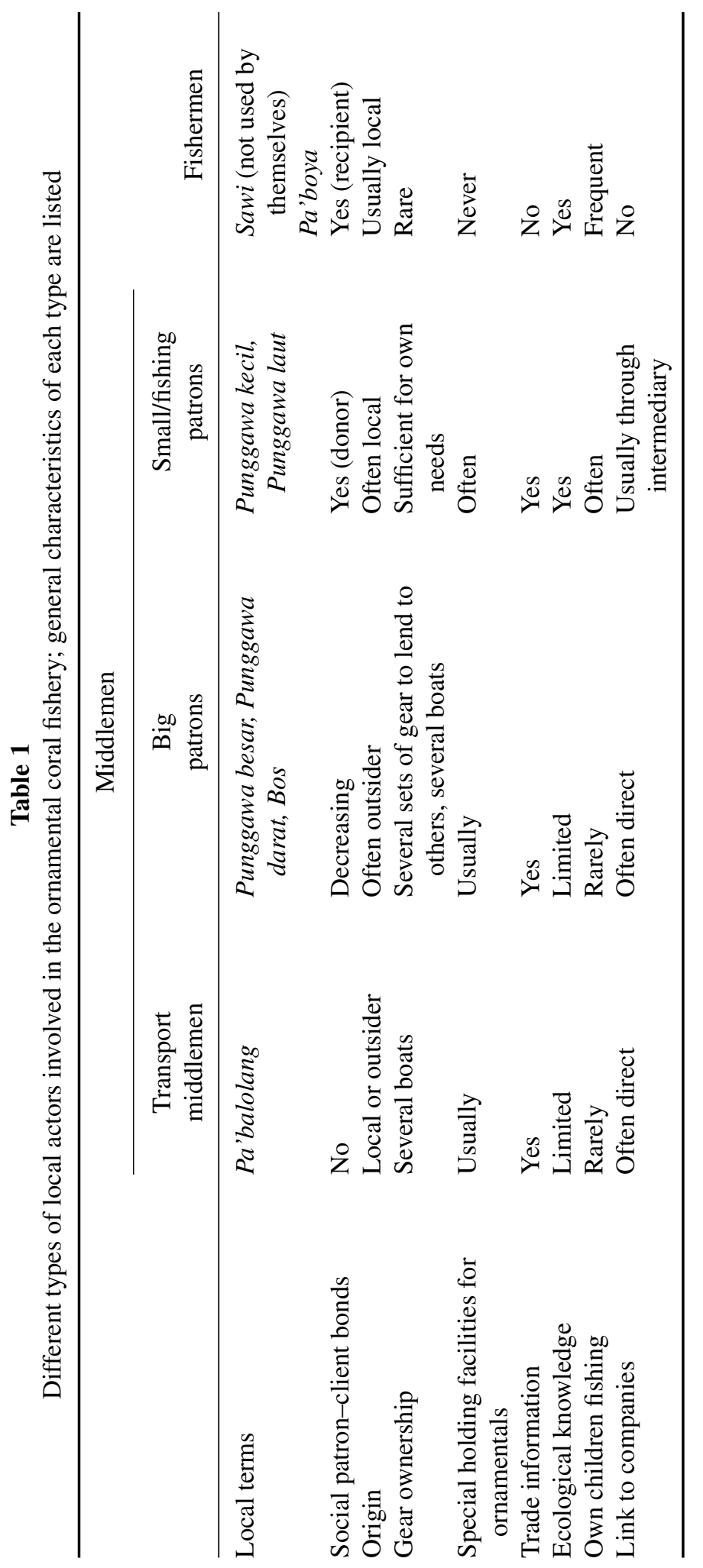




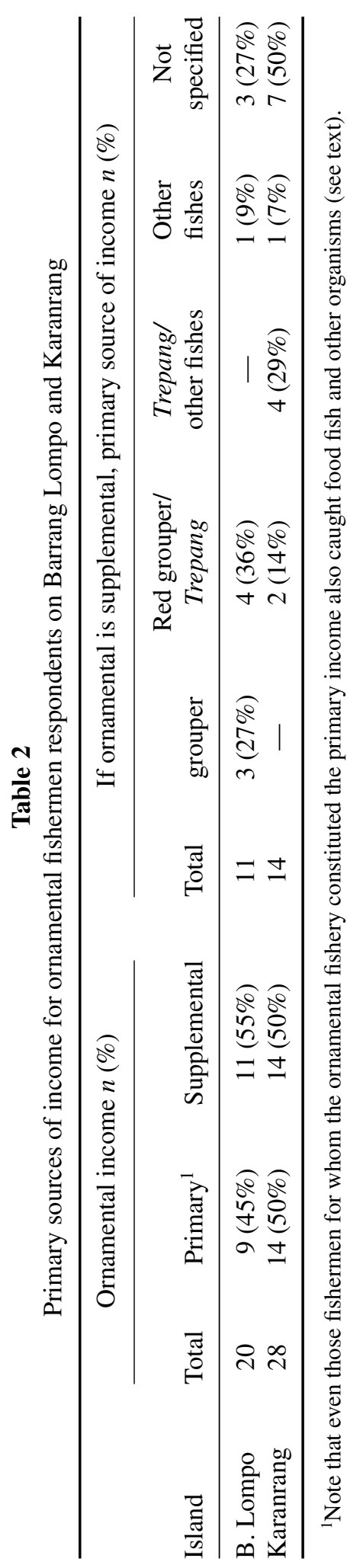


who collected corals as a supplementary income mostly came from the capture of grouper and/or the collection of trepang (sea cucumbers) (Table 2). The ornamental fishery showed distinct seasonality, with fishing activity and income from ornamentals being highest in the dry season (April-October).

Several factors contributed to establishing these two islands as centers of the ornamental coral fishery in Spermonde. Not surprisingly, spatial proximity to the mainland was important, since market demands could more easily be communicated and captured organisms more quickly transported than from more distant locations. Both islands also possessed infrastructure such as holding tanks necessary for catch sorting and storing, as well as good local knowledge of fishing techniques. This may at least partly be due to the fact that a large number of the fishermen on both islands were involved in the live sunu and trepang fisheries. The trade in live grouper requires the use of holding tanks, and compressor diving is frequently used for the capture of both species, which are consumed almost exclusively in China. A 2007 report states that $90 \%$ of the fishermen on Karanrang used compressors, and that cyanide use was widespread in the capture of red grouper for the live food fish trade (COREMAP 2007). Knowledge of this technique facilitated the adoption of coral collection as an additional activity: ornamental corals are usually collected by divers, with air supplied through a hose attached to a compressor operated on a boat above (hookah diving). Informants stated that they collected corals opportunistically while they were out searching for grouper or trepang and indeed, a recent study of the Spermonde trepang fishery shows that the main collection grounds for ornamental corals and trepang are almost identical (Dumestre 2010). Both groupers and trepang have been severely overfished for more than a decade (Johannes and Riepen 1995; Massin 1999), perhaps explaining why coral collection was taken up as additional activity.

All interviewed fishermen stated that in addition to collecting corals they catch food fish, either for their own consumption or for sale. Fishermen also targeted other organisms if market opportunities arose, but while they may have had the required knowledge on target species' habitats, they depended on the punggawas for information on what species were in demand on the market. An example of such opportunistic fishing is the bamboo coral, Isis hippuris, which was targeted by a large number of dive-fishermen in Spermonde between 2006 and 2008 when a new market emerged. The activity has since stopped due to apparent overfishing (Ferse et al. in press). As one fisherman from Karanrang put it, "We will take anything that looks like we might be able to sell it." In contrast, the middlemen of ornamental species were highly selective, buying only brightly colored specimens of species for which there was an expressed demand, usually in the form of orders from Makassar, Bali, or Jakarta. While the middlemen would sometimes inform fishermen on the quantity of corals they intended to buy beforehand, fishermen nonetheless usually collected a surplus of specimens, from which middlemen would then select those they deemed most marketable. Depending on species, fishermen would receive from 2,000 to 15,000 IDR per coral (equivalent to about 0.2-1.7 USD), while the trading companies in Makassar sold them for 10,000-50,000 IDR. The final retail price in European or U.S. shops is between 35 and 80 USD. While in an average week, fishermen would earn around 200,000 IDR from ornamental corals, the average income of patrons was about 10 times as high (see Table 3; both small punggawas reported an average income of 800,000 IDR, while the average weekly income of big punggawas from ornamentals was between 2,000,000 and 4,000,000 IDR).

As explained in more detail in the section on the legal organization of the fishery below, official harvest quotas form the legal basis for the ornamental coral fishery in Indonesia. Bruckner and Borneman (2006) report that harvest of the coral species Catalaphyllia 


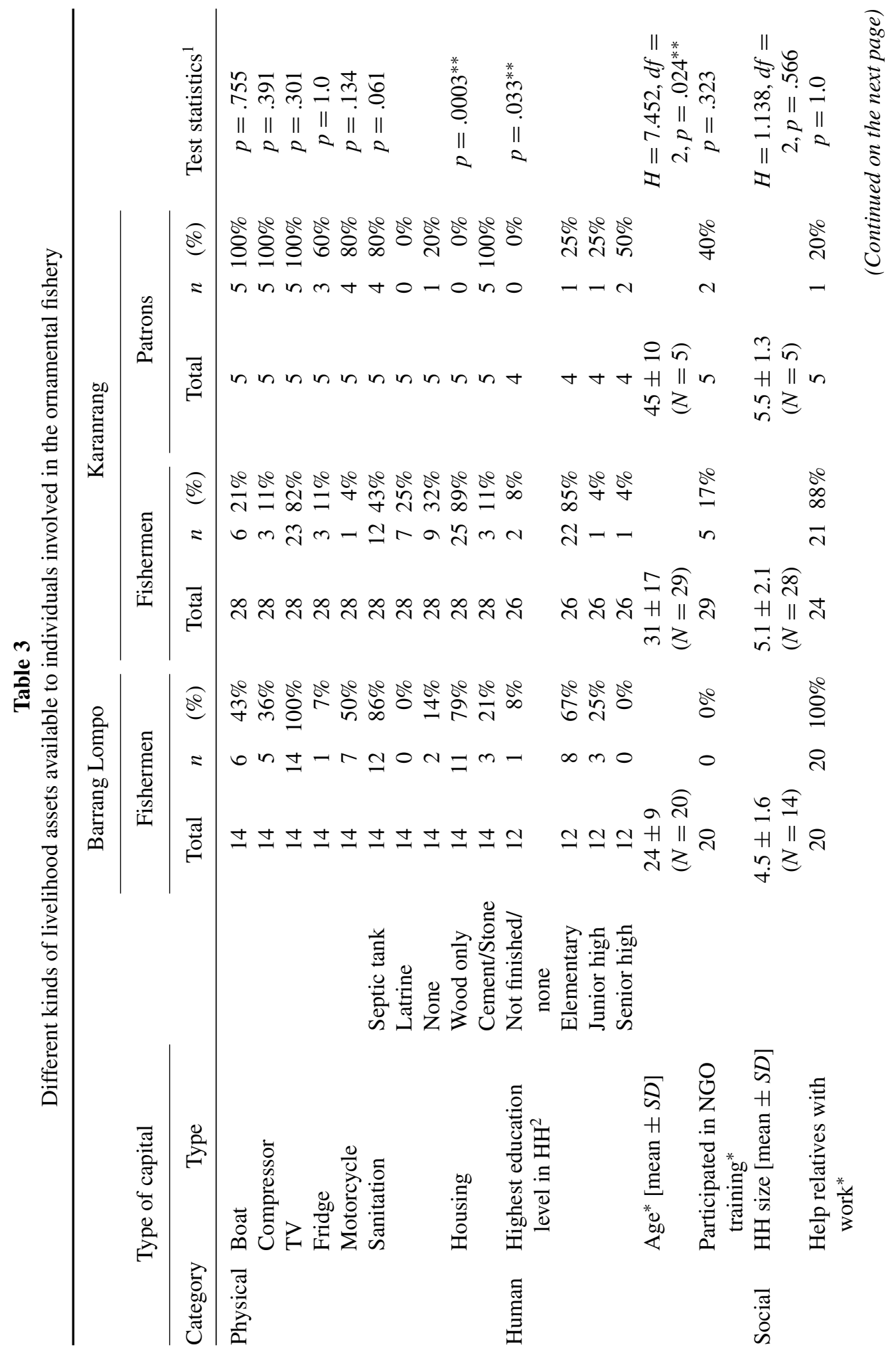




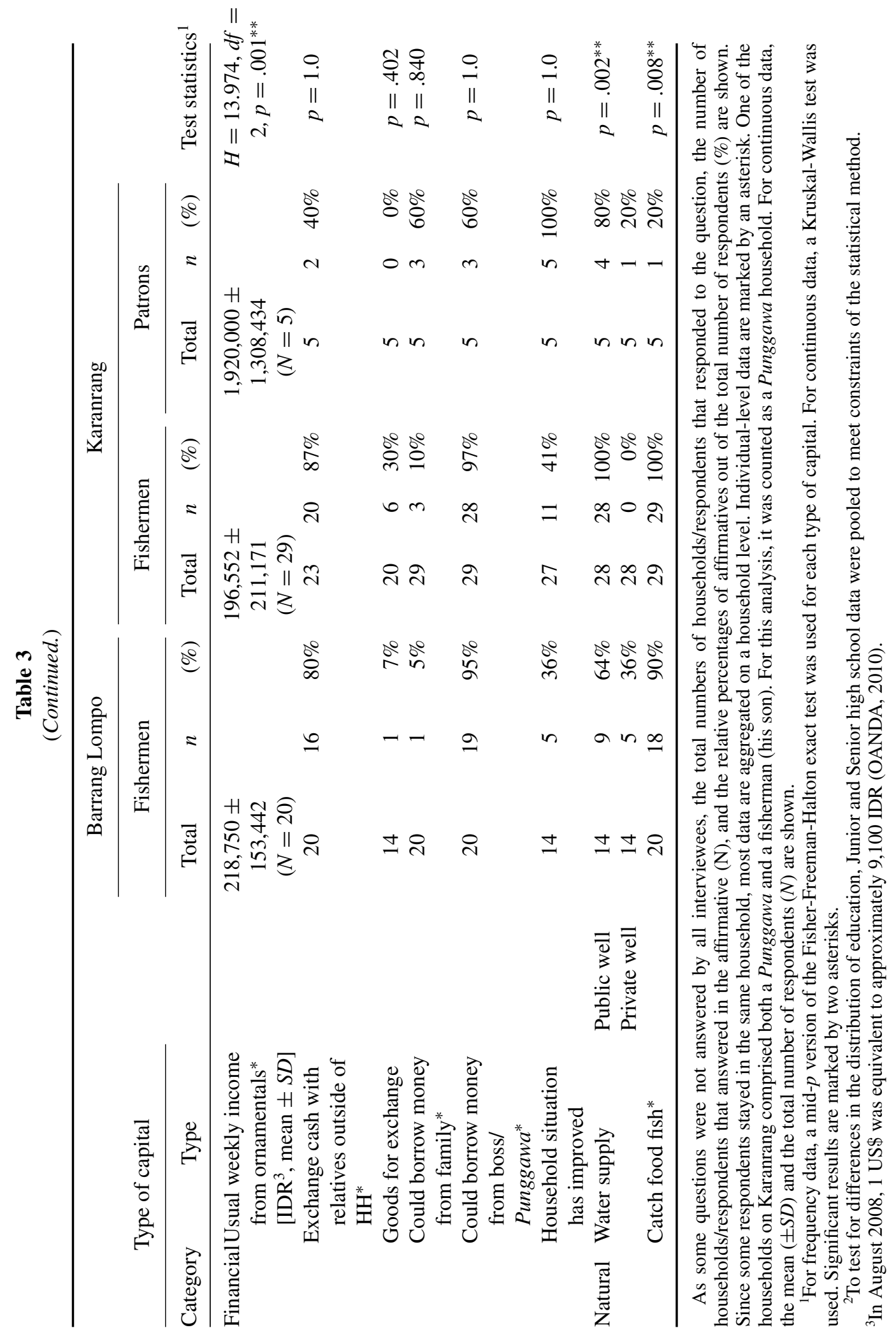


jardinei and Euphyllia cristata was allowed at unsustainable rates (the official annual quota of each species exceeding $70 \%$ of the total population as estimated by the authors of the study). Similarly, Yusuf (2005) observed that the quota for Blastomussa wellsi exceeded the amount of naturally occurring colonies that could be sustainably harvested by $2: 1$, and Knittweis and Wolff (2010) found that a harvest reduction of at least $60 \%$ was urgently needed for Heliofungia actiniformis polyps sized $4-11 \mathrm{~cm}$, the range most commonly targeted in the ornamental fishery. Clearly, harvest rates were not decided according to ecological criteria, and actual harvests appeared to be limited merely by the carrying capacity of fishing boats and the demand from patrons. Moreover, all corals which the fishermen were unable to sell were discarded. As a result, piles of discarded coral fragments were found scattered along the beach and next to patrons' houses on both islands.

\section{Development of the Fishery over Time}

All respondents stated to have begun the collection of ornamental corals from the mid-1990s onward, with the highest annual number of people entering the ornamental coral fishery in 2002 (Figure 2). An exception was one fisherman on Karanrang, who said that he had begun ornamental fishing around 30 years ago (ca. 1980). It was, however, not clear whether he was misjudging the time spent in the fishery. According to Syakir (2006), a Jakartabased company exporting ornamentals expanded its business to South Sulawesi toward the end of the 1980s. In the early 1990s, representatives of trading companies in Makassar began establishing themselves on Barrang Lompo and were expanding to other islands by the mid-1990s. This is reflected in the patterns found in the present study. Learning the techniques and obtaining training from traders (patrons or representatives of trading

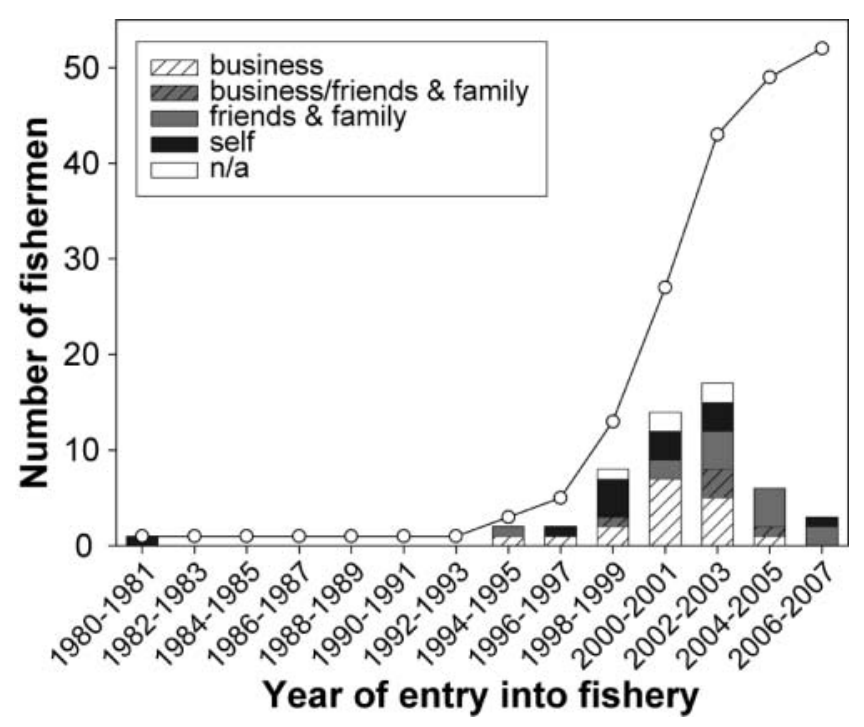

Figure 2. Cumulative number of fishermen in the ornamental coral fishery (circles), and number of fishermen entering the fishery each year, indicating their source of training in the fishery (bars). "Traders" comprises patrons and representatives of Makassar-based trading companies, and " $\mathrm{n} / \mathrm{a}$ " refers to respondents who did not want to disclose or did not remember who initially trained them in the fishery. 
companies), along with self-guided learning, drove the initial expansion of the ornamental fishery. From the year 2000 on, friends, parents and other family members increasingly became the main agents to pass on knowledge to those entering the ornamental fishery as newcomers (Figure 2). By 2003, the fishery appeared to have reached a degree of saturation in terms of number of fishermen that can partake under current conditions, since the number of new entrants levels off from then on.

\section{Collection Sites}

Coral collection areas vary by target species (Bruckner and Borneman 2006), with the location of habitats supporting the highly demanded bright color morphs differing in accordance with the individual coral species' ecology (Knittweis and Wolff 2010). Both study islands had distinct primary coral collection grounds located to their northwest and west, respectively (Figure 1). Interviewees stated that most collection sites were near the edge of the shelf area, far from the trade centers in Barrang Lompo and Karanrang. Here, underwater visibility is high, improving general working conditions. Moreover, nearshore areas were reported to be more intensely monitored for license enforcement (e.g., by water police), further deterring fishermen from these areas. By law, fishermen are required to carry copies of collection licenses (which are issued to the trading companies; see following section) with them when collecting.

Within these primary fishing grounds, fishermen differentiated and shifted among a high number of different locations for collecting corals. In other areas of Sulawesi, such frequent shifting between fishing grounds has been described as a conscious strategy for spreading fishing effort and conserving resources (Lowe 2006). It could, however, also be interpreted as a form of marine roving banditry, where fishermen move on to the next fishing ground once previously visited ones are exhausted (Berkes et al. 2006). The latter interpretation was at least partially correct for the Spermonde ornamental fishery. As successive reefs were overharvested, distances between the collector's home islands and harvesting areas have been steadily rising, causing an increase in transport times and costs. At present, fishermen from Karanrang are forced to embark on 3-4-day fishing trips when specifically targeting corals.

\section{Legal Organization of the Fishery}

The trade of all species of stony corals is regulated by the Convention on International Trade in Endangered Species (CITES), which stipulates that ratifying countries can only trade species if their export will not be detrimental to the species' survival. In order to ensure a sustainable harvest of corals and thus to implement CITES, Indonesia has adopted a number of principles. These include provisions that corals are only harvested from assessed sites, that targeted coral colonies or surrounding biota are not destroyed during collection, that harvest is done by trained fishermen only, and that coral fishermen undertake coral transplantation (Samedi and Liman 2002; Suharsano and Bruckner 2008). However, in contrast to these official principles, there was no indication of any regular official assessment of all coral harvest sites in Spermonde, nor did fishermen take special care during collection, or were even trained or encouraged to do so. Moreover, no coral transplantation by fishermen was observed or reported.

Forestry Ministry Decree (KepMenhut) No. 104/Kpts-II/2003 (Forestry Ministry 2003a) assigns the Natural Resources Conservation Board (Badan Konservasi Sumber 
Daya Alam, BKSDA) under the General Director for Environmental Conservation and Forest Protection (Perlindungan Hutan dan Konservasi Alam, PHKA) as the Management Authority for CITES in Indonesia. The scientific authority for determining collection quotas is assigned to the Indonesian Institute of Sciences (Lembaga Ilmu Pengetahuan Indonesia, LIPI), as specified in LIPI directorial decree (SK Kepala LIPI) No. 1973/2002 (LIPI 2002; see also Knittweis 2008; Yusuf 2005). LIPI research for the determination of catch quotas is financed by AKKII (Asosiasi Koral, Kerang dan Ikan hias Indonesia, the Indonesian Coral, Shell and Ornamental Fish Association), the business organization of Indonesian ornamental traders (I. Radjawali, personal communication, December 2011). However, two recent studies of ornamental coral collection in Spermonde concluded that harvest quotas neither took into account ecological criteria nor did they consider the realities of local harvesting practices (Bruckner and Borneman 2006; Knittweis and Wolff 2010). The licenses for coral collection are issued to trading companies, and state the names of middlemen and fishermen working for the company, as well as the types and amounts of corals permitted for collection. Patrons and fishers usually hold copies of the collection licenses from the companies they are selling to. However, while the amount of coral delivered to the trade companies usually agrees with that specified on the permit, the amount actually collected by fishermen is much higher, as explained above. Theoretically, as licenses are issued to trading companies, fishermen depend on middlemen with connections to officially recognized companies to be listed on licenses. However, although all ornamental fishermen should be listed on official trade licenses, almost none of the interviewees were on the official list of licensed fishermen provided by the responsible authority. Thus, although supposedly only registered fishermen were entitled to collect corals, and all collectors should carry copies of the licenses they were listed on, this official regulation de-facto was not functioning.

A major constraint to effective enforcement appeared to arise from conflicting and overlapping institutional responsibilities: while quota-setting and the issuing of licenses are handled by BKSDA, fishing grounds are patrolled by the provincial Department of Fisheries and Marine Affairs (Dinas Kelautan dan Perikanan, DKP), and the navy and water police in Makassar. Enforcement of fishery regulations is the responsibility of the water police, but many informants remarked that little enforcement takes place due to corruption. For instance, several informants mentioned that punggawas have achieved the release of fishermen convicted of using illegal methods by using their good relations with the police and navy (see also Idrus 2009). This has led to frustration among islanders who use legal methods and report offenders. In addition, patrolling of the collection grounds was rare due to lack of personnel, boats, and fuel. Furthermore, although some training on environmentally friendly ornamental fish collection was provided by the Marine Aquarium Council (MAC) in 2008, no international certification scheme for ornamentals from Spermonde, which under a functioning management and enforcement regime might act as an incentive for fishermen employing legal and sustainable harvest methods, is in place yet.

In sum, the implementation of laws and government regulations related to ornamental coral collection appeared largely dysfunctional.

\section{Informal Institutions and Networks}

In the face of dysfunctional official institutions, the fishery was governed by local, nonformal institutions. At the same time, it was strongly driven by demands from overseas markets. Fishing grounds surrounding the uninhabited islands in the archipelago were accessible to all fishermen, but fishing in the waters surrounding some of the inhabited islands required permission from local villagers (see Glaser et al. 2010b for a discussion 
of the conservation potentials of this emergent local institution). Access was usually only restricted for fishermen that used destructive fishing techniques (i.e., bomb and cyanide fishing). The specifics of restrictions differed between islands-sometimes, only cyanide would be banned, while in other cases, part of the catch would need to be shared with the local community (for further details on local rules, see Glaser et al. 2010b). While rules concerning marine resource use were evolving locally for waters surrounding inhabited islands, the behavior of fishermen targeting waters of uninhabited islands further from the mainland was mostly influenced by their dependence on particular patrons, who provided gear, demanded delivery of specific species of coral, and informed fishermen on the best harvesting grounds (see also the section on the regulatory role of the patron-client relationship).

Similar to other fisheries in the archipelago, the ornamental coral fishery is organized in the punggawa/sawi system, a hierarchical patron-client structure. Patron-client relationships are widespread within rural production systems such as small-scale fisheries, particularly in developing countries, and they have a long and well-documented history in Southeast Asia (see, e.g., Firth 1966; Merlijn 1989; Platteau and Nugent 1992; Ruddle 2011). In Spermonde, the punggawa/sawi system is common in generally the same structure in virtually all fishing activities, and it has existed in the region for centuries (Meereboer 1998; Pelras 2000; Schwerdtner Máñez and Ferse 2010). Mattudala (1995) distinguishes between big and small punggawas. Small punggawas usually focus on a single fishery and deal directly with the fishermen working for them, while punggawas that diversify their activities usually employ assistants (who often act as "small" punggawas) to aid in particular parts of the business, such as a single fishery. These kinds of patrons are referred to as big punggawas (see also Yusran 2002). As small punggawas usually acquire their own materials and possess their own starting capital, they are generally not in debt to the big patrons. Table 1 shows an overview of the different types of actors involved in the ornamental fishery on the islands, together with some of their characteristics. There are between 10-20 punggawas, and up to 15 fishermen can be linked to an individual "small" punggawa. While the bond between a traditional small punggawa and his clients usually involves both debt and social ties such as mutual trust, kinship and a feeling of obligation, in more recent activities such as the live reef fish trade, the relationship to big patrons is often of an exclusively financial nature, and these fisheries tend to be one among several business activities of big patrons. A strong emphasis on credits, debts, and market access is common, and patrons in such a relationship are often referred to as boss or "bos," the latter being an English language derivate used by the islanders (Meereboer 1998). Furthermore, some middlemen simply act as "transporters," providing the physical link between local punggawas and the market. They are locally known as pa'balolang and buy the catch from several punggawas and transport it to Makassar, where they are linked, either directly or through further intermediaries, to exporting companies. There is a tendency for the big, multi-business patrons not to provide the social services that small punggawas rely on to secure their relationships with fishermen-clients. Besides their links to small punggawas, big punggawas may also deal directly with fishermen, but these relationships are business-like in nature, with the patrons providing materials or credit only without offering any support in emergency situations (Krause et al. unpublished manuscript). While traditionally, punggawas would mostly focus exclusively on one type of fishery, one of the interviewed big patrons also traded trepang, and one of the small punggawas primarily traded fish and trepang. Fishermen were usually indebted to only one punggawa, to whom they sold their catch in order to repay their debt. They were then free to sell surplus catches, or organisms "their" patrons were not interested in (e.g., trepang and grouper), to other 
patrons. In contrast to artisanal food fisheries, where approximately $25 \%$ of the fishermen are independent from a punggawa (Ferse unpublished data), the number of independent fishermen in the ornamental coral fishery was smaller, at least partly due to the need for specific gear, licenses, and licenses. While selling to a patron without a debt bond would often result in better prices to the fishermen, this usually entailed a tradeoff, since such transactions precluded potential social obligations on the part of the buyers.

Table 3 gives an overview of the different livelihood assets available to fishermen and patrons. Only a minority of fishermen owned the fishing gear they use; for the majority, the relationship to a patron secured access to fishing gear. While conversations with other types of fishermen and on other islands indicated some reluctance toward compressor diving due to awareness of the associated health risks, a large number of fishermen appeared willing to venture into this activity if given the means to do so. The number and distribution of fishermen making use of compressor diving thus appeared to be driven predominantly by the presence of punggawas specializing in the marine products gathered by this kind of fishery. 95\% of the interviewed fishermen on Barrang Lompo, and 93\% of those on Karanrang, received compressors, boats, masks, and fins from patrons. Similarly, both of the interviewed small punggawas stated they had received their gear from their bosses, underlining they themselves were attached to patrons above them. Only one fisherman on Barrang Lompo used his own gear. On the other hand, all three large patrons owned equipment, which they lent to their client fishermen.

Management of finances is the traditional domain of island women. For instance, punggawas' wives were responsible for the accounting and overseeing their husbands' expenses. Women in fishing households frequently sold fruits, vegetables, and miscellaneous household items brought from Makassar, as well as homemade drinks and snacks. They thus supplemented household income, providing additional resources in times of hardship. A curious two-way trade in food fish was common: fish catches from the islands were usually sold entirely to Makassar city by traders and their families, while the fish consumed locally was usually cheap farmed fish shipped out to the islands from Makassar.

Social networks were quite extensive for both islands: all respondents had relatives living on their and on other islands, and the majority had relatives on the mainland and in Makassar. Among the peoples of South Sulawesi, kinship ties are of vital importance for social organization e.g. in enterprise and migration (Acciaioli 2000). Interviewed punggawas in different fisheries from a number of islands in the area frequently mentioned relatives in Makassar as an important prerequisite for entering trade. Individual small punggawas usually focused on one type of catch. Family ties among and between punggawas and fishermen thus helped to establish channels for the purchase and sale of a wider range of organisms. Family ties to other islands aided punggawas in broadening their networks of credit and debt by involving new fishermen that would deliver their catch to them. Extended networks helped to ensure a steady supply of catches to patrons when individual fishermen were unsuccessful during a fishing trip. This improves the patrons' ability to meet orders from companies in Makassar. The more fishermen contribute catches to a patron, the better they are able to compensate in case individual fishermen were unsuccessful. Big patrons that can draw on several punggawas to supply catch are thus in a better position than a traditional small punggawa with ties to only a few fishermen. In recent years, competition among punggawas for fishermen to provide labor and catch has been increasing. Similarly, fishermen regarded the relatives of their wives as a social and economic asset, to be called on, for instance, to provide fishing labor or access to punggawas on other islands. 


\section{Distribution of Knowledge}

Similar to small-scale fisheries elsewhere (Crona and Bodin 2010), patrons were not only important sources of fishing gear and credit, but also key knowledge brokers in the fishery. Only a small number of respondents on Karanrang received training from NGOs such as the Marine Aquarium Council (MAC) or the World Bank-funded Coral Reef Rehabilitation and Management Project (COREMAP). In general, patrons were in a better position than fishermen to gain access to these opportunities due to their status and social connections (Table 3). This reflects the observation of Glaser et al. (2010b) that training projects offered in the area frequently reached only a restricted number of people close to the local contact person. As a result, two big patrons on Karanrang but no fishermen were part of a local fishermen's cooperative. Such cooperatives are important for exchanging information on markets and prices. Ornamental trading companies in Makassar, although in strong competition with each other, have initiated such a network, the Sulawesi Coral and Ornamental Fish Association (AKIS). Fishermen affiliated with a particular punggawa tended to stick to their own group, and there were several instances of rivalry between groups associated with different punggawas. This may explain why local fishing cooperatives were rare. Such social divisions along patron-client lines pose a considerable challenge to management efforts that rely on the spread of information between members of assumedly homogeneous communities (Ferse et al. 2010).

During informal talks with fishermen in Spermonde throughout the study, statements indicating decreasing resources were frequently voiced. According to such statements by fishermen, CPUE declined by an estimated $90 \%$ for some ornamental fish species in the past ten years (I. Radjawali, personal communication, October 2009). Paradoxically, this decrease did not automatically mean that resources were viewed as finite. Patrons actively spread the opinion that natural resources are inexhaustible, and their attitude was reiterated by the fishermen. The respondents attributed the observed scarcity of targeted fish and sea cucumber species to natural variability, or assumed that the organisms had "moved elsewhere." Frequently, religious convictions were invoked to justify the belief in inexhaustible resources, despite widespread evidence to the contrary (see Martens 2009 for an account of fish-related local ecological knowledge among Spermonde fishermen). Furthermore, perceptions of resource decline differed significantly between respondents (Fisher-Freeman-Halton test, $p=.027$ ). Twelve of the fishermen on Barrang Lompo, and 14 on Karanrang, stated that the size or amount of targeted corals had decreased, although some also stated that no change had occurred ( 2 on Barrang Lompo and 9 on Karanrang). While both small punggawas said that the amount of target corals had decreased, none of the big patrons reported any changes, indicating that ecological information, such as on changes in catch, was not communicated from fishermen to traders. Since big patrons obtained corals from a large number of fishermen, decreased amounts of corals collected by individual fishermen might have gone unnoticed by the traders. As big patrons and small punggawas have usually made considerable investments into the fishery, they are likely to resist changes in resource use and to be unwilling to concede signs of overharvesting (see Crona and Bodin 2010). Moreover, as one respondent stated, "there is a punggawa for everything" fishermen are able to collect from the reef. Although the patrons discriminated against coral specimens of undesired color or shape (see above), the fishermen's perception that there is a demand for all marine products is likely to have reduced their concern over decreasing reef resources. 


\section{Regulatory Role of the Patron-Client Relationship}

While the debt-relationships between patrons and clients are sometimes criticized as exploitative and only of benefit to the patrons, in particular by government personnel or actors unfamiliar with the intricacies of the relationship (see, e.g., Idrus 2009, 127), patrons often also provide social security to clients, thereby reducing the socioeconomic vulnerability of fishermen in times of bad weather and other hardships (Platteau and Nugent 1992). Indeed, analyses across the globe show that a transition from the traditional multi-stranded bonds between patrons and clients towards single-stranded, exclusively economic relations between producers and purely business-focused traders is likely to increase the vulnerability of fishing households in the absence of alternative forms of social security (Glaser et al. 2010c; Ruthven and Kumar 2002; Wood 2003). While some fishermen mentioned that they would be glad to be free from the debt owed to their patron so as to sell their catch at higher prices, they were also mindful of the benefits offered by the attachment to a traditional punggawa. Idrus (2009) offers a multifaceted view of the punggawa-sawi system in Spermonde and the social and economic functions it assumes. Many informants confirmed that fishermen who are not in debt to a patron are free to choose whom to sell their catch to. Measures to avoid debt would thus foster competition among punggawas and are likely to increase the profit margin for fishers. Furthermore, several interviewed punggawas mentioned difficulties in finding sufficient numbers of fishers to work for them, underlining the two-way nature of the relationship. As a result, punggawas "compete" by offering good conditions (e.g., in terms of loans or social services) to their sawis, and perceptions of being treated "well" are an important factor for fishers to remain with a particular punggawa. However, decisions regarding changes in livelihood strategies often are not straightforward, but influenced by complex social, cultural, and institutional factors (Daw et al. 2012). Understanding under which conditions fishermen prefer credit schemes over ties to a punggawa, or would be willing to undergo more wide-ranging changes in livelihood strategies, requires further study.

Currently, borrowing from punggawas is a key coping strategy in times of hardship for Spermonde islanders. If their husbands were away on long fishing trips or could not go to sea as a result of bad weather, wives of fishermen obtained goods from small stores on the islands on credit, reducing their households' vulnerability to fluctuations in fishingdependent income. Such credit was provided by the husbands' punggawas, who added it to the debt of "their" fishermen. The punggawas also played a central role in trade: either directly or through middlemen, they were linked to traders in Makassar, and thus to markets for marine products that are exported but not consumed locally, such as ornamentals or sea cucumbers. Punggawas also ensured protection from law enforcement by their connections to the exporting companies, allowing the names of the fishermen working for them to be registered on the licenses for the collection of corals or other CITES-covered species. Furthermore, patrons (at least those with a focus on only one kind of marine product) usually provided fishermen with information on where particular species of coral could be found.

Patrons are thus a part of both the problem and the possible solution (see also Merlijn 1989 and Crona et al. 2010) in ornamental fisheries management: they channel demand and open market access by making connections to the exporting companies, thereby enabling the harvest of ornamental corals in the first place. As a comparably small group, they wield considerable influence over the ornamental fishery through financial and social ties, and can therefore play a key role in the management of the fishery. For example, by providing the expensive gear, licenses, and trade connections for the coral fishery, they essentially control access to the fishery. In the absence of this control over market and fishery access, 
the likelihood of a commons dilemma increases, as fishermen might compete to gather all available resources to sell them to buyers in Makassar. Punggawas can also influence which species and how many specimens are harvested, and they can demand that environmentally friendly methods are used during harvesting. As discussed above, the needed change in their attitudes is not likely without a fundamental re-organization of the fishery. The high amount of corals brought to the traders by fishermen that ends up discarded shows that the positive influence that patrons could potentially have on harvesting activities is not being harnessed at present. Nevertheless, the punggawa-sawi relationship emerges from this analysis as possessing substantial transformation potential for the ornamental coral fishery (sensu DFID 1999): it effectively determines the course of the fishery and the livelihood options available to the involved fishermen. For the development of formal fisheries management frameworks based on local marine tenure systems, Dahl (1988) identifies resource scarcity, resource boundaries, user group identification, limitations on technology, and economic organization as key factors. While the first two aspects are manifest in the natural environment of the reef fishery in Spermonde, the punggawa-sawi system is currently the major, if not only, framework within which to address the latter three aspects.

\section{Attitudes toward Mariculture Introduction}

In order for mariculture to constitute a realistic livelihood option and alternative to wild harvest of marine resources, existing constraints to its development need to be addressed. Assessing local attitudes and perceptions is an important first step. On Barrang Lompo, 16 of the interviewed fishermen $(80 \%)$ knew someone involved in coral farming. On the other hand, only one big patron and two of the interviewed fishermen on Karanrang knew mariculturists, and only one of these acquaintances was involved in coral farming. A single fisherman on Barrang Lompo, and two on Karanrang, stated they would start mariculture activity themselves. Two of these were the same people that knew other mariculturists, confirming that previous acquaintance with mariculture is an important precondition for a positive attitude toward mariculture (Miyata and Manatunge 2004). Coral and fish were the organisms these fishermen would choose to culture. Patrons were not interested in venturing into mariculture, as they perceived this as a riskier enterprise compared to relying on fishermen to provide them with ornamental corals. The main reasons for not wanting to begin mariculture are listed in Table 4.

Table 4

Reasons mentioned by interviewees for not wanting to attempt mariculture (multiple answers were possible)

\begin{tabular}{|c|c|c|c|c|c|c|}
\hline \multirow{3}{*}{$\frac{\text { Constraint }}{\text { Lack of know-how }}$} & \multirow{2}{*}{\multicolumn{2}{|c|}{$\begin{array}{c}\text { Barrang Lompo } \\
\begin{array}{c}\text { Fishermen } \\
(n=18)\end{array}\end{array}$}} & \multicolumn{4}{|c|}{ Karanrang } \\
\hline & & & \multicolumn{2}{|c|}{$\begin{array}{l}\text { Fishermen } \\
(n=14)\end{array}$} & \multicolumn{2}{|c|}{$\begin{array}{l}\text { Patrons } \\
(n=4)\end{array}$} \\
\hline & 8 & $44 \%$ & 5 & $36 \%$ & 2 & $50 \%$ \\
\hline Lack of finances & 12 & $67 \%$ & 1 & $7 \%$ & 0 & $0 \%$ \\
\hline Too difficult & 2 & $11 \%$ & 2 & $14 \%$ & 0 & $0 \%$ \\
\hline Too risky & 0 & $0 \%$ & 0 & $0 \%$ & 2 & $50 \%$ \\
\hline Other/no particular reason & 4 & $22 \%$ & 7 & $50 \%$ & 1 & $25 \%$ \\
\hline
\end{tabular}


When asked what they would need in order to start mariculture, only fishermen responded. Four respondents mentioned financial capital, one knowledge, and one materials. Based on these findings, it appears that on Barrang Lompo, where most respondents were familiar with coral mariculture, lack of finances and technical knowledge were the major constraints to mariculture development. On Karanrang, where only three of the respondents knew someone involved in mariculture, a general uncertainty regarding mariculture and the lack of specific knowledge appeared to be the major limiting factors.

An investment by patrons into activities not related to fishing is likely to increase their readiness to agree to management interventions changing prevailing fishing patterns, as they would be less dependent on the status quo for their income (Crona and Bodin 2010). The reluctance of patrons to venture into mariculture underlines that financial means are not the only limiting factor. Efforts to promote mariculture need to investigate the biology of candidate species and to demonstrate the feasibility of mariculture. Moreover, mariculture can have considerable environmental impacts (e.g., Naylor et al. 2000; Rönnbäck, Bryceson, and Kautsky 2002), although the impacts of ornamental mariculture are considered to be more benign than those of culturing organisms for consumption (Tlusty 2002). Both economic viability and environmental impacts need to be assessed in more detail before ornamental mariculture should be considered a realistic option in Spermonde. As long as integrated coastal management and monitoring of environmental impacts are insufficient, the large-scale promotion of mariculture needs to be treated with caution.

\section{Implications for Livelihood Development}

In contrast to many coastal and island locations elsewhere (e.g., Brugère, Holvoet, and Allison 2008 and references therein; Cinner, Marnane, and McClanahan 2005; Turner et al. 2007), there are few livelihood alternatives in Spermonde that do not depend on coral reef resources. A diversification into other activities is limited mainly by a lack of education, the absence of opportunities on the mainland, a lack of resources on the islands themselves, and, not least, by the reliance of most island households on patrons that specialize in marine products. The relatively small number of people engaged in the fishery and the low number of new entrants suggest that well-targeted socioeconomic management interventions, such as supplemental livelihood programs (Gillet et al. 2008), may be particularly effective in reducing the ecological impact of this fishery to a sustainable level (Kronen et al. 2010). Yet, important caveats remain. Without an adequate framework (e.g., in the form of regulation of access to the fishery), livelihood alternatives may be ineffective, or even lead to an intensification of fishing effort (Sievanen et al. 2005). Furthermore, if and how fishing households are able to tap into livelihood alternatives also depends on the wider socioeconomic context (Kronen et al. 2010).

The COREMAP project has developed a credit scheme under which all villages in the project area within the Spermonde Archipelago can access so-called village grants for infrastructure development, conservation measures, and capacity building (DKP 2006). However, due at least in part to the recent introduction of this program, credits have not been available to the majority of islanders (Glaser et al. 2010b).

A major constraint on the livelihood options of ornamental fishermen was the scarcity of available land and freshwater. While there is a limited amount of arable land available on Karanrang, a scarcity of freshwater makes farming activities almost impossible. On this island, most respondents received their water from one of the public wells, and several wells on the island were becoming increasingly salty at the time of the survey. On Barrang Lompo, the freshwater situation was better, and several fishermen had their own water 
sources. However, the island is very densely populated, and almost no land remains without construction on it. While Barrang Lompo had been able to supply fresh water to surrounding islands in the past, the wells on the island were just sufficient to meet the inhabitants' own needs at the time the present study was carried out. On both islands, access to the few available plots of land required permission from the village leadership.

Additional income generating activities mentioned as desirable by several respondents included ecotourism and small-scale business development. Yet, there is a discouraging local history of small-scale trainings (for instance, fishball-making and the manufacture of key chains with wood-carved seahorses), which failed because they found no markets. This underlines the fact that business managers need to be involved in alternative income trainings. Tourism development in the area is hampered by a lack of infrastructure (transport, accommodation, electricity, food and water availability) and, most importantly, by severe problems with ecosystem degradation and pollution coupled with a lack of awareness regarding these issues. Islanders also frequently mentioned that a supply of electricity beyond the current 5 hours per day would enable them to better pursue strategies such as small-scale selling of household items or the opening of food stalls. While households of middlemen and traders may have been able to supplement their electricity by using private generators, this option was too costly for fishing households. The majority of male youths opted to use their time to go fishing rather than pursuing a school education in quest of instant returns, both out of necessity and out of a desire for fast material gains. This further limited their access to non-fishing occupations.

The fishermen's belief that there are markets available for practically any marine resource, combined with the promotion of questionable ecological views by punggawas, reduced local concerns over decreasing resources. Moreover, while an awareness of the connection between unsustainable harvest and resource degradation and a perception of crisis can contribute to management success (Pollnac, Crawford, and Gorospe 2001), a change in fishing behavior can be prevented by other factors. Lack of time, knowledge, positive examples, funding, and material support led to a high reluctance among fishermen to develop supplementary livelihoods such as mariculture. In times of low fishing activity, fishing households had to rely on punggawas to meet their needs, thus increasing their dependence and vulnerability.

\section{The Role of Patrons in Livelihood Development and Management Strategies}

Punggawas might play a prominent role in an integrated and holistic management approach. They are the link between fishermen, markets, and fishing technology, yet are often overlooked in fisheries management (Yusran 2002; Krause et al. unpublished manuscript). They potentially hinder livelihood diversification beyond fisheries for at least two reasons: by opening up markets for a wide range of marine resources, and, as opinion leaders, by preventing the development of perceptions of resource crisis among fishermen (Crona et al. 2010). Furthermore, due to their sometimes high investments into fishing gear, they are likely to resist changes in marine resource use (Crona and Bodin 2010). These factors need to be considered when designing management approaches. As long as the development of social safety nets and credit schemes for poorer fisherfolk is not adequate, management needs to acknowledge the critical role of punggawas based on their links to fishermen and product markets. Their careful inclusion in conservation planning also increases the chances for reaching a large number of fishermen with a relatively small effort. In the face of unreliable law enforcement and fishery monitoring, marshalling the support of punggawas in the interest of the sustainability of their trade may enable better management of 
the fishery. This should entail targeted efforts to change their attitudes and behavior, so as to influence "their" fishermen. At the same time, holistic management needs to strengthen the capacities and position of fishermen vis-à-vis patrons in order to establish checks and also to avoid re-enforcing preexisting inequalities. Important steps in this direction may be the provision of low-interest credits to fishermen outside the sphere of influence of the punggawas to cope with seasonality in fishing, and efforts to enable fishers not linked to punggawas to be listed on the collection licenses of trading companies. Attachment to particular patrons seems a major factor preventing the fishermen from organizing themselves (e.g., in the form of fishing cooperatives). This particular point requires further attention, as self-organization may help to increase the bargaining power of fishers toward patrons and enable them to demand a higher share of the profits derived from ornamentals. However, in the absence of adequate fisheries management, this could lead to a further unchecked increase in fishing effort, and support in self-organization should thus form part of a wider management strategy. Toward this end, self-organization could allow fishers to become involved in formal monitoring and quota setting efforts, and enable them to become eligible for fishing licenses without depending on patrons and trading companies. Common objectives should be jointly developed by fishermen, punggawas and managers. The reasons why previous NGO trainings predominantly reached punggawas rather than fishermen need to be examined and programs with improved access for fishermen designed.

\section{Recommendations for Multi-Level Management}

The current state of the fishery does not bode well for the conservation of the coral reefs of Spermonde. Despite being one of the most important ornamental coral fisheries in Indonesia, the activity in Spermonde is not very specialized. As long as the perception of open resource access and unlimited market potential for a wide range of marine commodities prevails, the collectors' level of concern with the sustainability of this fishery is likely to be limited. Currently, the number of active fishers seems to have reached a saturation level. However, as global demand for marine ornamentals continues to rise and most fishermen in Spermonde act opportunistically, switching to new target species if market access arises, it is likely that more fishermen will add ornamentals to their portfolio of targeted organisms if given the chance. The present regulation of the ornamental fishery appears to be ineffective. Current collection grounds are far from the mainland and from inhabited islands, so that both government policing and regulations by island communities are likely to be insufficient for the management of the fishery. Thus, both local fishermen and punggawas will have to play a more active role in management. One example on how to achieve this comes from Tanzania, where local residents serve as the lowest tier in a nested fisheries management program, providing data and ecological feedback to higher levels of management and science (de la Torre-Castro 2006). Another exists in the Marine Extractive Reserves in Brazil which effectively mobilize local monitoring and sanctioning efforts (Diegues 2008; Glaser et al. 2010c). If the active participation of such local stakeholders is neglected, outcomes may instead be counterproductive (Ferse et al. 2010). For example, the Indonesian ministerial decree that regulates the capture of wild animals stipulates that collection within national parks, nature reserves, game reserves, recreation areas and nature conservation areas is not allowed (Forestry Ministry 2003b). Currently, a high number of local notake areas are being established throughout Spermonde in the frame of the COREMAP project, and there are plans to integrate the whole area into one large marine protected area (MPA) with several zones (Glaser et al. 2010b). Unless the regulations are modified to permit sustainable harvesting within designated zones of the MPA, conflicts with coral 
collectors are likely to arise, threatening conservation goals. A reduction in the number of permissible collection sites without a parallel decrease in catch quotas will lead to the concentration of harvesting activity on a few areas, so that even previously benign levels of harvest may locally increase beyond sustainable levels (Harriott 2003). Similarly, current strategies of the Indonesian government to increase fisheries production and improve the wellbeing of coastal fishing communities include plans to provide fishing gear, access to loans and markets, and to deregulate fishing enterprises (see Article 4 in MoMAF 2010). The present analysis indicates that this strategy might in fact increase overfishing and resource degradation, thus endangering fishing-dependent livelihoods.

Improved management efforts are needed to prevent further degradation and to set the stage for an effective conservation of the region's coral reefs. Government Regulation 7/1999 (Government of Indonesia 1999) on the Preservation of Flora and Fauna, which forms the basis for the population management of ornamental corals, explicitly provides the legal basis for local communities to become involved in population monitoring (e.g., by integrating them in fisheries monitoring). Furthermore, a number of recent regulations on marine management include provisions for local communities to participate in the development and implementation of management plans for coastal and small island waters (Siry 2011). Such integrative co-management has the potential to steer the fishery toward a more sustainable path (see also Samedi and Liman 2002). Three key "actor nodes" of the fishery require specific management interventions: (1) individual fishermen, (2) small and big punggawas, and (3) government institutions (including regulation of exporters in Makassar). All measures should be part of an integrated, holistic approach.

At the level of individual fishermen, recommended measures are:

- Improve the local understanding of ecological processes underlying the fishery, including the concept of sustainable harvesting. While fisherfolk have some local knowledge on species habitats, abundances, and changes in these, the fact that resources are finite and are rapidly being depleted by human activities is seldom appreciated. Similar convictions are common elsewhere in Indonesia (e.g., Majors 2008). Environmental education could build upon the existing perception of decreasing catches and sizes, but needs to challenge the currently prevailing assumption that marine resources are inexhaustible. Crona and Bodin (2010) recommend working with influential opinion leaders that do not have high capital investments in the fishery. In Indonesia, this could be attempted for example by working with religious leaders in the fishing communities. At the same time, fishermen should be included in the generation and analysis of ecological data used to set quotas and monitor the resources as much as possible, as stipulated in Government Regulation No. 7/1999. Doing so would both support an improved understanding of ecological processes and involve fishermen in the management process, thus increasing the potential to render it more responsive to local rationalities and perceptions.

- Improve access to market information for the ornamental coral trade and enable fishermen to become registered on fishing licenses independent of patrons. Improved transparency along the ornamental trade chain from foreign consumer to the Spermonde fishermen with regard to species and amounts in demand would help to increase fisheries selectivity and constitute a step toward the establishment of a certification scheme. It may also improve the bargaining position of fishermen towards their punggawas, though this effect will be reduced by debt ties between fishermen and punggawas and through lack of competition for clients among individual punggawas. The direct listing of fishermen or fishing cooperatives on fishing 
licenses, which would reduce their dependence on patrons, could be brokered by the regional Fishery Department, as part of a process to include fisherfolk in fisheries monitoring.

- Carefully design and implement credit schemes to decrease fisherfolks' need to borrow from punggawas. As confirmed by interviewed fishermen, indebtedness is one of the major factors curtailing their choice to turn to alternative, non-fishing income-generating activities. Debt often forces fishermen to adopt unsustainable fishing methods. Financing schemes are part of many coastal development and management programs such as for instance the COREMAP program, which is active in parts of Spermonde (DKP 2006). However, the implementation of this program needs to be improved to ensure that credit schemes are accessible to larger sections of the island communities (Glaser et al. 2010b).

- Make use of legal provisions that allow local communities to participate in the development of coastal zone and marine resource use management plans. In return for their collaboration in resource monitoring and fisheries data collection, fishermen could be encouraged to form local organizations endowed with territorial use rights and with opportunities for collaborating in quota setting and for obtaining fishing licenses. Including fishers in monitoring, zoning and quota setting, and assigning to them exclusive use rights to identified territories and direct access to fishing licenses, would increase the chance that this important group develops self-interest in the sustainability of the fishery.

- Create conditions that allow for the development of livelihood alternatives outside fisheries and thus reduce extractive pressure on the reefs. The preliminary assessment of attitudes toward mariculture showed that currently, the large majority of fishermen and middlemen are for various reasons not keen to engage in mariculture. Changing this attitude would require a comprehensive approach, beginning with market analysis and site selection, the establishment of pilot projects and environmental impact studies, comprehensive training and credit schemes as well as long-term financial and technical assistance. Pilot projects should target fishermen as well as punggawas since the latter have made high investments in the fishery, channel demand, and provide market access, thus ultimately driving fishing activities. If mariculture is to be pursued as a locally feasible alternative livelihood strategy, additional research is needed to arrive at an in-depth understanding of local motivations and attitudes relating to fisheries and potential alternatives.

In relation to the small and big punggawas, the following recommendations can be made:

- Improve communication with fishermen about which species are sought for the market in order to decrease the amount of discarded corals. This measure would allow fishermen to use their time more efficiently, and to receive higher returns for their efforts, as less time would be spent on collecting corals they are unable to sell. It would also reduce the amount of discarded corals, which would be desirable for punggawas if discarded corals were included in their total allowable catch quota (see recommendations for government institutions).

- Enlist the help of punggawas in the promotion of ecological awareness among fishermen to change the currently prevalent belief in god-given inexhaustible marine resources. While coral reef management programs frequently include efforts to raise the environmental awareness of fishermen, ecological training should be offered to punggawas as well. As influential opinion leaders they are in a central position to 
influence collection activities, yet are not always well informed about ecological change since, as traders, they have little direct contact with the reef ecosystem.

- Institutionalize feedback on ecological conditions at the collection grounds by establishing mandatory reporting on collected species to government authorities (see de la Torre-Castro 2006). Punggawas usually have invested sufficiently into the ornamental trade (e.g., by establishing links to traders in Makassar, or by building holding facilities) to be interested in the sustainability of the fishery. This could be used as a starting point to establish collaborations between them and regulatory authorities, for example by stipulating that patrons and fishers listed on licenses submit regular reports on the amount of corals harvested to the authorities.

- In return for their efforts, punggawas should be given opportunities to participate in business and best management practice training programs to improve their knowledge on international market demands as well as on the shipping and handling of specimens. Furthermore, financial support for holding facilities could be provided. The granting of funds, training and trade licenses should be contingent upon ongoing evaluations of the reporting and communication performance of punggawas.

At the level of government institutions and exporters, regulations of the ornamental fishery need to match local ecological realities, and their enforcement needs to be improved. This requires better use of scarce resources, strategic links between island institutions and government agencies, and stronger scientific data on the state of resources. Recommended measures are:

- Promoting research on the ecology of targeted coral specimens. In line with Government Regulation No. 7/1999, local communities should be actively involved in the monitoring of natural resources. Designing management plans for the Spermonde coral trade will require an increase of local knowledge about coral ecology and life history characteristics (Knittweis and Wolff 2010).

- Random, unannounced controls of exporters and middlemen. Instead of trying to patrol large collection grounds, the scarce resources available should be devoted to controlling the bottlenecks of the fishery.

- Improved cooperation between regulatory and enforcement agencies, with an external auditing system to combat corruption in enforcement. Punggawas convicted of bribing officers should lose their trade licenses. Recent efforts by the Indonesian government to curb corruption give hope that this problem can be effectively addressed.

- Better training of fisheries officers to allow them to recognize and distinguish collected species. Currently, misidentification of species hinders the effective control of quotas.

- Development of a mandatory catch reporting system for punggawas. Similar to bycatch in fisheries, quotas should include discarded corals. Quotas should be set by weight or number depending on which measure is more suitable for the species in question. The granting of licenses should be contingent on accurate reporting, to be controlled by unannounced point checks. Mechanisms are needed to incorporate feedback on abundances and fishing pressure in quota setting and regulation of fishing pressure to ensure that management can adapt to changing ecological conditions.

- A formal and adaptive framework to incorporate community actors and institutions into a hybrid form of management that merges bottom-up and top-down regulations (Cinner and Aswani 2007). The legal basis for such co-management is provided 
in recent regulations such as Law 27/2007 (Siry 2011). This approach can draw on experiences with incorporating community-based marine tenure systems into formal fisheries management (Dahl 1988). For fishing grounds in island waters, the granting of territorial use rights should include assigning the right to island communities to establish their own use rules and to enforce these. For remote fishing grounds, the assignment of site-specific collection quotas to punggawas and their fishermen or to fishermen cooperatives should be considered and jointly agreed-on rules on permissible fishing technology and benefit sharing be developed.

- Moving beyond the dogma of increasing fishery production as a means to improve fisherfolk livelihoods. The inclusion of strategies to foster mariculture production in current fisheries development plans (MoMAF 2010) is a first step into this direction. However, it still carries considerable risks (e.g., in the form of negative environmental impacts). Additional efforts need to be directed into developing livelihood options that do not depend on the extraction of marine resources. Furthermore, to reduce fisheries and other, for instance climate change-related pressures in the island environments, government agencies should consider supporting islanders wishing to look for occupation and residence on the mainland with housing, credit, and professional training.

\section{Conclusion}

The Spermonde ornamental coral fishery was found to be a non-specialized activity that forms part of a wider marine resource use portfolio. Its status as one among many activities, the lack of non-fisheries alternatives, lack of a local perception of ecological crisis, dysfunctional official marine resource management, and prevailing patron-client ties have all contributed to a lack of sustainability in the fishery. To improve the situation, strengthening of the position of fishers and their inclusion in monitoring, zonation, and quota-setting schemes, helping fishers to independently obtain licenses, as well as finding an adequate role for the patron-client institution in a form of co-management are recommended. From the side of the government agencies, this will require the willingness to delegate authority to the local level, in return for the prospect of improved monitoring and enforcement. The danger of collusion and corruption between traders and enforcement agencies remains, and the success of fisheries management will depend on how well these structural problems can be addressed. Discussions with individual punggawas and fisheries officers indicate, however, that many are sincere in their willingness to work toward a sustainable ornamental fishery. In the long term, a well-monitored and sustainably conducted ornamental fishery which is accompanied by adequately targeted and supported supplementary livelihood efforts could be a key component of a conservation strategy that builds upon both ecological and socioeconomic realities.

\section{References}

Acciaioli, G. 2000. Kinship and debt. The social organization of Bugis migration and fish marketing at Lake Lindu, Central Sulawesi. Bijdragen tot de Taal-, Land- en Volkenkunde 156 (3): 588-617. Allison, E. H., and F. Ellis. 2001. The livelihoods approach and management of small-scale fisheries. Marine Policy 25 (5): 377-388.

Barber, C. V., and V. R. Pratt. 1997. Sullied seas. Strategies for combating cyanide fishing in Southeast Asia and beyond. Washington, DC: World Resources Institute (WRI).

Berkes, F., T. P. Hughes, R. S. Steneck, J. A. Wilson, D. R. Bellwood, B. Crona, C. Folke, et al 2006. Globalization, roving bandits, and marine resources. Science 311 (5767): 1557-1558. 
BPS. 2009. Kecamatan Liukang Tupabbiring Dalam Angka. Pangkajene, Indonesia: Central Board of Statistics (BPS) Pangkep Regency.

BPS. 2010. Makassar Dalam Angka. Makassar, Indonesia: Regional Development Planning Board (BAPPEDA), Central Board of Statistics (BPS).

Bruckner, A. W. 2002. Surveys of coral collection sites in the Spermonde Archipelago, South Sulawesi. Proceedings of the International Workshop on the Trade in Stony Corals: Development of Sustainable Management Guidelines. April 9-12, 2001, Jakarta, Indonesia.

Bruckner, A. W., and E. H. Borneman. 2006. Developing a sustainable harvest regime for Indonesia's stony coral fishery with application to other coral exporting countries. Proceedings of the 10th International Coral Reef Symposium. June 28-July 2, 2004, Okinawa, Japan.

Brugère, C., K. Holvoet, and E. H. Allison. 2008. Livelihood diversification in coastal and inland fishing communities: Misconceptions, evidence and implications for fisheries management. Working Paper, Sustainable Fisheries Livelihoods Programme (SFLP) Rome, Italy: FAO/DFID.

Bunce, L., P. Townsley, R. S. Pomeroy, and R. Pollnac, eds. 2000. Socioeconomic manual for coral reef management. Townsville, Australia: Global Coral Reef Monitoring Network (GCRMN), Australian Institute of Marine Science (AIMS).

Burke, L., K. Reytar, M. Spalding, and A. Perry. 2011. Reefs at risk revisited. Washington, DC: World Resources Institute (WRI).

Burke, L., E. Selig, and M. Spalding. 2002. Reefs at risk in Southeast Asia. Washington, DC: World Resources Institute (WRI).

Butcher, J. G. 2004. The closing of the frontier: A history of the marine fisheries of Southeast Asia, c. 1850-2000. Leiden, The Netherlands: KITLV Press.

Cinner, J. E., and S. Aswani. 2007. Integrating customary management into marine conservation. Biological Conservation 140 (3-4): 201-216.

Cinner, J. E., M. J. Marnane, and T. R. McClanahan. 2005. Conservation and community benefits from traditional coral reef management at Ahus Island, Papua New Guinea. Conservation Biology 19:1714-1723.

COREMAP. 2007. Rencana pengelolaan terumbu karang desa Mattiro Sulu Kecamatan Liukang Tupabbiring Kabupaten Pangkep. Pangkajene, Indonesia: Coral Reef Rehabilitation and Management Program (COREMAP) II, South Sulawesi Office.

Crawford, B. 2002. Seaweed farming: An alternative livelihood for small-scale fishers? Narragansett, RI: Coastal Resources Center, University of Rhode Island.

Crona, B., and Ö. Bodin. 2010. Power asymmetries in small-scale fisheries: A barrier to governance transformability? Ecology and Society 15 (4): 32.

Crona, B., M. Nyström, C. Folke, and N. Jiddawi. 2010. Middlemen, a critical social-ecological link in coastal communities of Kenya and Zanzibar. Marine Policy 34 (4): 761-771.

Dahl, C. 1988. Traditional marine tenure: A basis for artisanal fisheries management. Marine Policy 12 (1): 40-48.

Daw, T. M., J. E. Cinner, T. R. McClanahan, K. Brown, S. M. Stead, N. A. J. Graham, and J. Maina. 2012. To fish or not to fish: Factors at multiple scales affecting artisanal fishers' readiness to exit a declining fishery. PLoS ONE 7 (2): e31460.

de la Torre-Castro, M. 2006. Beyond regulations in fisheries management: The dilemmas of the "beach recorders" Bwana Dikos in Zanzibar, Tanzania. Ecology and Society 11 (2): 35.

DFID. 1999. Sustainable livelihoods guidance sheets: Section 2. London, UK: Department for International Development.

Diegues, A. C. 2008. Marine protected areas and artisanal fisheries in Brazil. Chennai, India: International Collective in Support of Fishworkers (ICSF).

DKP. 2006. Pedoman Umum Pengelolaan Berbasis Masyarakat, Coral Reef Rehabilitation and Management Program (COREMAP). Jakarta, Indonesia: Departemen Kelautan dan Perikanan (DKP), Direktorat Jenderal Kelautan, Pesisir, dan Pulau-Pulau Kecil.

Dumestre, M. 2010. An analysis of the holothurian fishery and associated socio-economic issues in Spermonde Archipelago (South Sulawesi, Indonesia). Bremen, Germany: University of Bremen (MSc thesis). 
Edinger, E. N., J. Jompa, G. V. Limmon, W. Widjatmoko, and M. J. Risk. 1998. Reef degradation and coral biodiversity in Indonesia: Effects of land-based pollution, destructive fishing practices and changes over time. Marine Pollution Bulletin 36 (8): 617-630.

Ellis, F. 1998. Household strategies and rural livelihood diversification. Journal of Development Studies 35 (1): 1-38.

Ellis, F. 2000. Rural livelihoods and diversity in developing countries. Oxford, UK: Oxford University Press.

Erdmann, M. V. 1995. An ABC guide to coral reef fisheries in Southwest Sulawesi, Indonesia. Naga, the ICLARM Quarterly 18: 4-6.

Ferse, S. C. A., M. Glaser, M. Neil, and K. Schwerdtner Máñez. In press. To cope or to sustain? Eroding long-term sustainability in an Indonesian coral reef fishery. Regional Environmental Change.

Ferse, S. C. A., M. Máñez Costa, K. Schwerdtner Máñez, D. S. Adhuri, and M. Glaser. 2010. Allies, not aliens: Increasing the role of local communities in marine protected area implementation. Environmental Conservation 37 (1): 23-34.

Firth, R. 1966. Malay fishermen. Their peasant economy. London, UK: Routledge \& Kegan Paul.

Forestry Ministry. 2003a. Decree of the Minister of Forestry 104/Kpts-II/2003. Assignment of the General Director for Environmental Conservation and Forest Protection as the Management Authority for CITES in Indonesia.

Forestry Ministry. 2003b. Decree of the Minister of Forestry 447/Kpts-II/2003. Administration of Collection or Capture and Distribution of Wild Plants and Animals.

Gillet, R., G. Preston, W. J. Nash, H. Govan, T. Adams, and M. Lam. 2008. Livelihood diversification as a marine resource management tool in the Pacific Islands: Lessons learned. SPC Fisheries Newsletter 125:32-39.

Glaser, M., I. Radjawali, S. C. A. Ferse, and B. Glaeser. 2010a. "Nested" participation in hierarchical societies? Lessons for social-ecological research and management. International Journal of Society Systems Science 2 (4): 390-414.

Glaser, M., W. Baitoningsih, S. C. A. Ferse, M. Neil, and R. Deswandi. 2010b. Whose sustainability? Top-down participation and emergent rules in marine protected area management in Indonesia. Marine Policy 34 (6): 1215-1225.

Glaser, M., G. Krause, R. S. Oliveira, and M. Herazo-Fontalvo. 2010c. Mangroves and people: A social-ecological system. In Mangrove dynamics and management in North Brazil, eds. U. Saint Paul and H. Schneider, 307-354. Heidelberg, Berlin, Germany: Springer.

Government of Indonesia. 1999. Government Regulation No. 7/1999. Preservation of Plant and Animal Species.

Harriott, V. J. 2003. Can corals be harvested sustainably? Ambio 32 (2): 130-133.

Hoegh-Guldberg, O. 1999. Climate change, coral bleaching and the future of the world's coral reefs. Marine and Freshwater Research 50 (8): 839-866.

Hoegh-Guldberg, O., P. J. Mumby, A. J. Hooten, R. S. Steneck, P. Greenfield, E. Gomez, C. D. Harvell, et al 2007. Coral reefs under rapid climate change and ocean acidification. Science 318 (5857): 1737-1742.

Hopley, D., and Suharsono, eds. 2000. The status of coral reefs in eastern Indonesia. Townsville, Australia: Global Coral Reef Monitoring Network (GCRMN), Australian Institute of Marine Science (AIMS).

Idrus, M. R. 2009. Hard habits to break. Investigating coastal resource utilisations and management systems in Sulawesi, Indonesia. Christchurch, New Zealand: University of Canterbury (PhD thesis).

Job, S. 2005. Integrating marine conservation and sustainable development: Community-based aquaculture of marine aquarium fish. SPC Live Reef Fish Information Bulletin 13:24-29.

Johannes, R. E., and M. Riepen. 1995. Environmental, economic, and social implications of the live reef fish trade in Asia and the Western Pacific. Arlington, VA: The Nature Conservancy.

Jones, R. 2008. CITES, corals and customs: The international trade in wild coral. In Advances in coral husbandry in public aquariums, eds. R. J. Leewis and M. Janse, 351-361. Arnhem, The Netherlands: Burgers' Zoo. 
Knittweis, L. 2008. Population demographics and life history characteristics of Heliofungia actiniformis: A fungiid coral species exploited for the live coral aquarium trade in the Spermonde Archipelago, Indonesia. Bremen, Germany: University of Bremen ( $\mathrm{PhD}$ thesis).

Knittweis, L., and M. Wolff. 2010. Live coral trade impacts on the mushroom coral Heliofungia actiniformis in Indonesia: Potential future management approaches. Biological Conservation 143 (11): 2722-2729.

Krause, G., L. Knittweis, I. Radjawali, and S. C. A. Ferse. The role of linkages and level-dependent drivers in a social-ecological system of Spermonde, South Sulawesi (Indonesia): The case of the ornamental trade. Unpublished manuscript.

Kronen, M., A. Vunisea, F. Magron, and B. McArdle. 2010. Socio-economic drivers and indicators for artisanal coastal fisheries in Pacific island countries and territories and their use for fisheries management strategies. Marine Policy 34 (6): 1135-1143.

LIPI. 2002. Surat Keputusan (SK) Kepala LIPI No. 1973/2002.

Lowe, C. 2006. Wild profusion: biodiversity conservation in an Indonesian archipelago. Princeton, NJ: Princeton University Press.

Lundquist, C. J., and E. F. Granek. 2005. Strategies for successful marine conservation: Integrating socioeconomic, political, and scientific factors. Conservation Biology 19 (6): 1771-1778.

Majors, C. 2008. Seas of discontent: Conflicting knowledge paradigms within Indonesia's marine environmental arena. In Biodiversity and human livelihoods in protected areas: Case studies from the Malay Archipelago, eds. N. S. Sodhi, G. Acciaioli, M. Erb, and A. K.-J. Tan, 241-265. Cambridge, UK: Cambridge University Press.

Martens, S. E. 2009. Fishing in the Spermonde Archipelago. An ethnographic study of local ecological knowledge. Hamburg, Germany: University of Hamburg (MA thesis).

Massin, C. 1999. Reef-dwelling Holothuroidea (Echinodermata) of the Spermonde Archipelago (South-West Sulawesi, Indonesia). Zoologische Verhandelingen Leiden 329: 1-144.

Mattulada, H. A. 1995. Traditional management among Bugis-Makassar Entrepreneurs in South Sulawesi. Lontara 1 (2): 23-28.

Meereboer, M.-T. 1998. Fishing for credit: Patronage and debt relations in the Spermonde Archipelago, Indonesia. In Living through histories. Culture, history and social life in South-Sulawesi, eds. K. Robinson and M. Paeni, 249-276. Canberra, Australia: Department of Anthropology, Research School of Pacific and Asian Studies, The Australian National University.

Merlijn, A. G. 1989. The role of middlemen in small-scale fisheries: A case study of Sarawak, Malaysia. Development and Change 20: 683-700.

Miclat, E. F. B., J. A. Ingles, and J. N. B. Dumaup. 2006. Planning across boundaries for the conservation of the Sulu-Sulawesi Marine Ecoregion. Ocean \& Coastal Management 49 (9-10): 597-609.

Miyata, S., and J. Manatunge. 2004. Knowledge sharing and other decision factors influencing adoption of aquaculture in Indonesia. International Journal of Water Resources Development 20 (4): 523-536.

MoMAF. 2010. Peraturan Menteri Kelautan dan Perikanan Republik Indonesia Nomor Per.12/MEN/2010 tentang MINAPOLITAN.

Moorhead, J. A., and C. Zeng. 2010. Development of captive breeding techniques for marine ornamental fish: A review. Reviews in Fisheries Science 18 (4): 315-343.

Naylor, R. L., R. J. Goldburg, J. H. Primavera, N. Kautsky, M. C. M. Beveridge, J. Clay, C. Folke, J. Lubchenco, H. Mooney, and M. Troell. 2000. Effect of aquaculture on world fish supplies. Nature 405 (6790): 1017-1024.

Niehof, A. 2004. The significance of diversification for rural livelihood systems. Food Policy 29 (4): 321-338.

Norse, E. A., and L. B. Crowder, eds. 2005. Marine conservation biology. The science of maintaining the sea's biodiversity. Washington, DC: Island Press.

Parks, J. E., R. S. Pomeroy, and C. M. Balboa. 2003. The economics of live rock and live coral aquaculture. In Marine ornamental species: Collection, culture, and conservation, eds. J. C. Cato and C. L. Brown, 185-206. Ames, IA: Iowa State Press. 
Pelras, C. 2000. Patron-client ties among the Bugis and Makassarese of South Sulawesi. Bijdragen tot de Taal-, Land-en Volkenkunde 156:393-432.

Pet-Soede, C., W. L. T. Van Densen, J. S. Pet, and M. A. M. Machiels. 2001. Impact of Indonesian coral reef fisheries on fish community structure and the resultant catch composition. Fisheries Research 51:35-51.

Platteau, J. P., and J. Nugent. 1992. Share contracts and their rationale: Lessons from marine fishing. Journal of Development Studies 28 (3): 386-422.

Pollnac, R. B., B. R. Crawford, and M. L. G. Gorospe. 2001. Discovering factors that influence the success of community-based marine protected areas in the Visayas, Philippines. Ocean \& Coastal Management 44:683-710.

Polunin, N. V. C. 1983. The marine resources of Indonesia. Oceanography and Marine Biology: An Annual Review 21:455-531.

Pomeroy, R. S., and C. M. Balboa. 2004. The financial feasibility of small-scale marine ornamental aquaculture in the Philippines. Asian Fisheries Science 17:365-376.

Raymakers, C. 2001. Review of trade in live corals from Indonesia. Brussels, Belgium: TRAFFIC Europe.

Rönnbäck, P., I. Bryceson, and N. Kautsky. 2002. Coastal aquaculture development in Eastern Africa and the Western Indian Ocean: Prospects and problems for food security and local economies. Ambio 31 (7): 537-542.

Ross, M. A. 1984. A quantitative study of the stony coral fishery in Cebu, Philippines. Marine Ecology 5 (1): 75-91.

Ruddle, K. 2011. "Informal" credit systems in fishing communities: Issues and examples from Vietnam. Human Organization 70 (3): 224-232.

Ruthven, O., and S. Kumar. 2002. Moving mud, shifting soil: Change and development in wage labour livelihoods in Uttar Pradesh, India. Working Paper 176. London, UK: Overseas Development Institute.

Ruxton, G., and M. Neuhäuser. 2010. Good practice in testing for an association in contingency tables. Behavioral Ecology and Sociobiology 64 (9): 1505-1513.

Sale, P. F., R. K. Cowen, B. S. Danilowicz, G. P. Jones, J. P. Kritzer, K. C. Lindeman, S. Planes, et al 2005. Critical science gaps impede use of no-take fishery reserves. Trends in Ecology and Evolution 20 (2): 74-80.

Samedi, and P. D. Liman. 2002. Management measures and CITES trade controls for the stony coral trade in Indonesia. International Workshop on the Trade in Stony Corals: Development of Sustainable Management Guidelines. Jakarta, Indonesia.

Schwerdtner Máñez, K., and S. C. A. Ferse. 2010. The history of Makassan Trepang fishing and trade. PLOS ONE 5 (6): e11346.

Scoones, I. 1998. Sustainable rural livelihoods. A framework for analysis. IDS Working Paper 72. Sussex, UK: Institute of Development Studies (IDS).

Sievanen, L., B. Crawford, R. Pollnac, and C. Lowe. 2005. Weeding through assumptions of livelihood approaches in ICM: Seaweed farming in the Philippines and Indonesia. Ocean \& Coastal Management 48 (3-6): 297-313.

Siry, H. Y. 2011. In search of appropriate approaches to coastal zone management in Indonesia. Ocean \& Coastal Management 54 (6): 469-477.

Suharsano, and A. W. Bruckner. 2008. Evaluation of non-detriment finding for trade in stony corals from Indonesia. International Expert Workshop on CITES Non-Detriment Findings. WG 9-Aquatic Invertebrates, Case Study 5. November 17-22, 2008, Cancun, Mexico.

Syakir, M. 2006. Socio-economic importance of marine ornamental fishery at Spermonde Archipelago, South Sulawesi-Indonesia. Bremen, Germany: University of Bremen (MSc thesis).

Tlusty, M. 2002. The benefits and risks of aquacultural production for the aquarium trade. Aquaculture 205 (3-4): 203-219.

Tomascik, T., A. J. Mah, A. Nontji, and M. K. Moosa. 1997. The ecology of the Indonesian Seas. Part one. Singapore: Periplus Editions. 
Turner, R., A. Cakacaka, N. Graham, N. Polunin, M. Pratchett, S. Stead, and S. Wilson. 2007. Declining reliance on marine resources in remote South Pacific societies: Ecological versus socio-economic drivers. Coral Reefs 26 (4): 997-1008.

Wabnitz, C., M. Taylor, E. Green, and T. Razak. 2003. From ocean to aquarium. The global trade in marine ornamental species. Cambridge, UK: UNEP World Conservation Monitoring Centre.

Watson, I. 2000. The role of the ornamental fish industry in poverty alleviation. NRI Report 2504. Kent, UK: Natural Resources Institute.

Wood, G. 2003. Staying secure, staying poor: The "Faustian bargain." World Development 31 (3): $455-471$.

Yusran, M. 2002. Ponggawa-sawi relationship in co-management: An interdisciplinary analysis of coastal resource management in South Sulawesi, Indonesia. Halifax, Canada: Dalhousie University ( $\mathrm{PhD}$ thesis).

Yusuf, S. 2005. Metode penentuan kuota perdagangan karang hias yang lestari dari Kepulauan Spermonde, Makassar (Sustainable quota setting method of aquarium trade coral from Spermonde Archipelago, Makassar). Torani 15 (3): 211-220. 